\title{
Involvement of chitinases of Bacillus thuringiensis during pathogenesis in insects
}

\author{
Mark N. Sampson† and Graham W. Gooday
}

Department of Molecular and Cell Biology, Institute of Medical Sciences, Foresterhill, Aberdeen AB25 2ZD, UK
Author for correspondence: Graham W. Gooday. Tel: +44 1224 273147. Fax: +44 1224273144. e-mail: g.w.gooday@abdn.ac.uk

Bacillus thuringiensis subsp. israelensis IPS78 and B. thuringiensis subsp. aizawai HD133 both secreted exochitinase activity when grown in a medium containing chitin. Allosamidin, a specific chitinase inhibitor, inhibited activity from both strains, with $\mathrm{IC}_{50}$ values of about $50 \mu \mathrm{M}$ with colloidal chitin as substrate and between 1 and $10 \mu \mathrm{M}$ with 4-methylumbelliferyldiacetylchitobioside and 4-methylumbelliferyl-triacetylchitotrioside as substrates. The involvement of these chitinolytic activities during pathogenesis in insects has been investigated with B. thuringiensis subsp. israelensis IPS78 against larvae of the midge Culicoides nubeculosus, and with B. thuringiensis subsp. aizawai HD133 against caterpillars of the cotton leafworm Spodoptera littoralis. Presence of $100 \mu \mathrm{M}$ allosamidin increased the $L_{50}$ by factors of 1.3 and 1.4 , respectively, demonstrating a role for bacterial chitinases in the attack on the insects. Presence of chitinase A from Serratia marcescens considerably decreased the values for LD $_{50}$ confirming previous observations with different systems of the potentiation of entomopathogenesis of $B$. thuringiensis by exogenous chitinases. The most likely action of the endogenous chitinases of $B$. thuringiensis is to weaken the insects' peritrophic membranes, allowing more ready access of the bacterial toxins to the gut epithelia. Addition of exogenous chitinases will then increase this effect. Complementary cross-infection experiments, strain HD133 against midge larvae and strain IPS78 against caterpillars, were performed to investigate the pathogen/host specificities of the effects. Results showed that much higher concentrations of bacteria were required to achieve even low mortalities, and addition of chitinase A gave no increase in death rate.

Keywords: chitinase, peritrophic membrane, Bacillus thuringiensis toxin, allosamidin, entomopathogenesis

\section{INTRODUCTION}

Chitin, the $(1,4)-\beta$-linked homopolysaccharide of $N$ acetylglucosamine, occurs in insects as a major component of the cuticle and of the peritrophic membrane, a protective sleeve lining the gut of many insects. Pathogens that infect through the gut must penetrate this chitin-rich barrier. Chitinase activities may play key roles in the virulence of some pathogens that infect insects via the peritrophic membrane, including the

†Present address: Warwick International Group Ltd, Mostyn, Holywell, Flintshire CH8 9HE, UK.

Abbreviations: (GICNAC) ${ }_{2}, N, N^{\prime}$-diacetylchitobiose; (GICNAC) ${ }_{3}, N, N^{\prime}, N^{\prime \prime}-$ triacetylchitotriose; (GlcNAC) $4, N_{1} N^{\prime}, N^{\prime \prime}, N^{\prime \prime \prime}$-tetraacetylchitotetraose; $\mathrm{IC}_{50}$ concentration causing $50 \%$ inhibition; $\mathrm{LD}_{50}$, dose causing $50 \%$ mortality; 4-MeUmb, 4-methylumbelliferone. malarial parasite Plasmodium gallinaceum (Huber et al., 1991), the trypanosome Leishmania (Schlein et al., 1991), the nematode Brugia malayi (Fuhrman et al., 1995) and Autographa californica nucleopolyhedrovirus (Hawtin et al., 1997). In this study we have examined the role of chitinases in the pathogenesis of Bacillus thuringiensis, which produces a range of insecticidal protein crystalline inclusion bodies during sporulation. Several strains are used worldwide as biological control agents against major insect pests. Classification of $B$. thuringiensis isolates is on the basis of their flagellar serotypes, with different serotypes displaying distinctive virulence profiles against a range of dipteran or lepidopteran larvae (deBarjac, 1981).

There have been reports that addition of commercial chitinase preparations (Smirnoff, 1974), crude chitinase 
preparations from Bacillus circulans (Wiwat et al., 1996), and even of chitinolytic bacteria extracted from the insect's gut (Sneh et al., 1983), enhance the insecticidal activity of $B$. thuringiensis. These preparations, however, will have contained contaminating enzymes, such as proteases, which may also enhance insecticidal activity. Therefore the exogenous bacterial chitinase used in this study was a single enzyme, chitinase A from Serratia marcescens, expressed in Escherichia coli. Regev et al. (1996) reported that this recombinant enzyme synergistically enhanced the activity of recombinant $B$. thuringiensis $\delta$-endotoxin CryIC against larvae of Spodoptera littoralis.

Chitin is degraded to its monomer by the chitinolytic enzyme system. Chitinases (EC 3.2.1.14) consist of endochitinases, which randomly cleave within the chitin chain, and exochitinases, which progressively hydrolyse diacetylchitobiose units from the end of the chitin chain. The products of chitinase action are further degraded to $\mathrm{N}$-acetylglucosamine by $\mathrm{N}$-acetylglucosaminidases (EC 3.2 .1 .52 ). Chitinases serve a variety of functions in nature including morphogenesis, defence, nutrition and pathogenesis (Gooday, 1994). As part of the study we have used allosamidin, a specific chitinase inhibitor produced by Streptomyces spp. (Sakuda et al., 1987a, b). It is a pseudo-trisaccharide containing $\mathrm{N}$-acetylallosamine and has been used to study inhibition of chitinase activity in a number of biological systems (Gooday, 1990; Gooday et al., 1988; Milewski et al., 1992; Shahabuddin et al., 1993).

Here we report on the chitinolytic activity of two strains of $B$. thuringiensis, inhibition of activity by allosamidin and the effect of addition of exogenous chitinase or allosamidin on their insecticidal activity. B. thuringiensis subsp. israelensis has strong larvicidal activity against a range of dipteran pests (deBarjac, 1990) and here we have used it against the larvae of the blood-sucking midge Culicoides nubeculosus. Many species of Culicoides are pests of man and domestic animals and are vectors of virus diseases in commercial livestock (Kettle, 1977). We have also used B. thuringiensis subsp. aizawai against caterpillars of the cotton leafworm Spodoptera littoralis. The cotton leafworm is found throughout Africa, Europe and the Middle East and causes damage to a wide range of crops (Carter, 1984).

\section{METHODS}

Chemicals. Glycol chitin was prepared from glycol chitosan (Sigma) using the method of Trudel \& Asselin (1989). Regenerated chitin was prepared from practical grade chitosan (Sigma) using the method of Molano et al. (1977). 4Methylumbelliferyl glycosides of $N$-acetylglucosamine oligosaccharides [4-MeUmb-(GlcNAc) ${ }_{1-4}$ ] (Sigma) were prepared at $0.8 \mathrm{mM}$ : in water for the monomer, dimer and trimer glycosides and in $50 \%$ ethanol for the tetramer glycoside. All stocks were stored at $-20^{\circ} \mathrm{C}$.

Bacterial strains. B. thuringiensis subsp. israelensis IPS78 and $B$. thuringiensis subsp. aizawai HD133 were provided by $\mathrm{Dr}$ D. J. Ellar (University of Cambridge, UK) and were routinely grown and maintained on nutrient agar (Oxoid CM3). E. coli strain A992 harbouring the pSL3ChiAII plasmid expressing the chitinase A gene from $S$. marcescens was the gift of Professor I. Chet (Hebrew University of Jerusalem, Israel) and was grown on L-broth containing ampicillin $\left(100 \mu \mathrm{g} \mathrm{ml}^{-1}\right)$.

Preparation of culture supernatants. The two $B$. thuringiensis strains were grown in a chitinase-inducing medium consisting of regenerated chitin $(0.4 \%)$, Oxoid yeast extract $(0.05 \%)$, $\left(\mathrm{NH}_{4}\right)_{2} \mathrm{SO}_{4}(0 \cdot 1 \%), \mathrm{MgSO}_{4} .7 \mathrm{H}_{2} \mathrm{O}(0.03 \%), \mathrm{KH}_{2} \mathrm{PO}_{4}(0.6 \%)$, $\mathrm{K}_{2} \mathrm{HPO}_{4}(1 \%)$; the $\mathrm{pH}$ was adjusted to 7 prior to autoclaving. Cultures were grown with shaking for $72 \mathrm{~h}$ at $30^{\circ} \mathrm{C}$ and the supernatant fraction harvested by centrifugation $(13000 \mathrm{~g}$, $30 \mathrm{~min}$ ). Culture supernatants were concentrated tenfold using an Amicon Centriprep 10 Microconcentrator with a $10 \mathrm{kDa}$ cut-off membrane, and stored at $-20^{\circ} \mathrm{C}$ until used for chitinase assays.

Chitinase assays. Chitinase activity and inhibition by allosamidin were measured by assaying the supernatant extracts in the presence of increasing concentrations of allosamidin $(0-100 \mu \mathrm{M})$ using two microtitre plate fluorescence assays. The first utilizes glycol chitin as a substrate in the presence of Calcofluor White M2R (4,4'-diamino-2,2'-stilbene disodium sulfonic acid), a fluorescent brightener (Sampson \& Gooday, 1996). Breakdown of glycol chitin was monitored by measuring the decrease in fluorescence against time and activities were calculated as katals, by equating chitin degradation with the equivalent number of moles of $N, N^{\prime}$-diacetyl-glycolchitobiose. Calcofluor assay mixtures contained $65 \mu \mathrm{l}$ sample, $75 \mu \mathrm{l}$ glycol chitin suspension $(0 \cdot 18 \%, \mathrm{w} / \mathrm{v}), 10 \mu \mathrm{l}$ Calcofluor White M2R stock solution $(0.1 \% \mathrm{w} / \mathrm{v}), 10 \mu \mathrm{l}$ allosamidin solution (0-2 mM) or water and $40 \mu \mathrm{l} 0.1 \mathrm{M}$ citric acid/0.2 M dibasic sodium phosphate buffer $(\mathrm{pH} 6)$. All assays were read every $5 \mathrm{~min}$ for $30 \mathrm{~min}$ at $37^{\circ} \mathrm{C}$, and performed in six replicates.

Levels of activity were also determined using the 4-methylumbelliferyl glycoside assay according to the method of McCreath \& Gooday (1992). Samples were assayed against the four fluorogenic substrates [4-MeUmb-(GlcNAc) $\left.{ }_{1-4}\right]$, which allow measurement of different enzyme activities within the chitinolytic system, with hydrolysis of 4-MeUmb-GlcNAc, 4-MeUmb-(GlcNAc) ${ }_{2}$, 4-MeUmb-(GlcNAc) $)_{3-4}$ detecting $\mathrm{N}$ acetylglucosaminidase, exochitinase and endochitinase activities, respectively (Kuranda \& Robbins, 1987; McCreath \& Gooday, 1992). For each of the substrates, enzyme activity was calculated using a calibration curve which converted change in fluorescence to concentration of free 4-methylumbelliferone released (McCreath \& Gooday, 1992). The 4methylumbelliferyl assay mixtures contained $25 \mu \mathrm{l}$ of sample, $5 \mu \mathrm{l}$ of one of the four fluorogenic substrate solutions $(0.8 \mathrm{mM})$ [4-MeUmb-(GlcNAc) $\left.{ }_{1-4}\right], 10 \mu$ l allosamidin solution $(1 \mathrm{mM}-10 \mu \mathrm{M})$ and $60 \mu \mathrm{l}$ of the citrate/phosphate buffer $(\mathrm{pH}$ 6), and were incubated for $30 \mathrm{~min}$ at $37^{\circ} \mathrm{C}$. The reaction was stopped by the addition of $100 \mu 1 \mathrm{M}$ glycine/ $\mathrm{NaOH}$ stop buffer and fluorescence was measured immediately. All assays were performed in six replicates. Fluorescence readings for all assays were measured at excitation $355 \mathrm{~nm}$, emission $460 \mathrm{~nm}$, using a Fluoroskan II microtitre plate fluorimeter.

Preparation of chitinase A extract. E. coli A992 cells carrying plasmid pSL3ChiAII were grown for $20 \mathrm{~h}$ at $37^{\circ} \mathrm{C}$ in L-broth containing ampicillin $\left(100 \mu \mathrm{g} \mathrm{m}^{-1}\right)$ and $0.1 \mathrm{mM}$ phenylmethylsulfonyl fluoride. The cells were removed by centrifugation and the supernatant fraction concentrated 20 -fold by ultrafiltration using an Amicon Centriprep 10 Microconcentrator with a $10 \mathrm{kDa}$ cut-off membrane, and then lyophilized to a final concentration of $500 \mu \mathrm{g}$ protein $\mathrm{ml}^{-1}$. Preparations were stored at $-20^{\circ} \mathrm{C}$ until used for bioassay purposes. 
Insect larvae and bioassays. Larvae of the midge C. nubeculosus and the cotton leafworm $S$. littoralis were used for bioassays. The bacteria were grown for $2 \mathrm{~d}$ at $30^{\circ} \mathrm{C}$ on nutrient agar plates and cultures were then scraped off, resuspended in $1 \mathrm{ml}$ sterile deionized water and lyophilized. Stock suspensions of lyophilized plate cultures were prepared for both strains of $B$. thuringiensis by resuspending cells in sterile deionized water at a concentration of $10 \mathrm{mg} \mathrm{ml}^{-1}$.

The effect of chitinase on the insecticidal activity of strain IPS78 against midge larvae was studied using five treatments. Portions of $500 \mu \mathrm{l}$ of the bacterial stock suspension $(10 \mathrm{mg}$ $\mathrm{ml}^{-1}$ ) were added to $500 \mu \mathrm{l}$ of distilled water, or of $1 \mathrm{mM}$ allosamidin solution, or of chitinase A extract at three concentrations $\left(50,125\right.$ or $250 \mu \mathrm{g}$ protein $\left.\mathrm{ml}^{-1}\right)$. The resultant bacterial suspensions were diluted to give a range of dose levels, and $250 \mu \mathrm{l}$ portions of each were added to $3 \mathrm{ml}$ deionized water containing 25 fourth-instar midge larvae and incubated at $27^{\circ} \mathrm{C}$. Bioassay readings were performed in duplicate and mortalities were recorded after $3 \mathrm{~d}$. Each experiment was repeated on a separate day. All data from replicates were pooled and analysed by probit analysis (Finney, 1962). The lethal dose required to kill $50 \%$ of the larvae $\left(\mathrm{LD}_{50}\right)$ was determined by linear regression of these values.

The rate of killing of strain IPS78, with and without added chitinase, was assessed by adding $500 \mu \mathrm{l}$ of the stock bacterial suspension to $500 \mu \mathrm{l}$ of either chitinase A solution $(125 \mu \mathrm{g}$ protein $\mathrm{ml}^{-1}$ ) or distilled water. The resultant suspensions were diluted to give suspensions containing $1.5 \mathrm{mg}$ and $0.8 \mathrm{mg}$ bacteria $\mathrm{ml}^{-1}$. Portions of $250 \mu \mathrm{l}$ of these were added to $3 \mathrm{ml}$ deionized water containing 25 fourth-instar midge larvae, and incubated at $27^{\circ} \mathrm{C}$. All readings were performed in duplicate and mortalities were recorded every $12 \mathrm{~h}$ for $4 \mathrm{~d}$. Each experiment was repeated on a separate day.

The effect of chitinase on the insecticidal activity of strain HD133 against newly hatched first-instar larvae of $S$. littoralis was studied in a similar fashion. Portions of $500 \mu \mathrm{l}$ of the bacterial stock suspension were added to $500 \mu \mathrm{l}$ of distilled water, or of $1 \mathrm{mM}$ allosamidin solution, or of chitinase $A$ extract at two concentrations (50 and $100 \mu \mathrm{g}$ protein $\mathrm{ml}^{-1}$ ). The resultant bacterial suspensions were diluted to give a range of dose levels, and $250 \mu \mathrm{l}$ portions of each were added to $2 \mathrm{~cm}$ cubes of an artificial diet (Bot, 1967). Twenty newly hatched larvae were put onto each cube and incubated at $27^{\circ} \mathrm{C}$. Experiments were done in duplicate and mortalities recorded after $4 \mathrm{~d}$. Each experiment was repeated on a separate day. All data from replicates were pooled and analysed as before.

The rate of killing of strain HD133, with and without added chitinase, was assessed by adding $500 \mu \mathrm{l}$ of the stock bacterial suspension to $500 \mu \mathrm{l}$ of either chitinase A solution $(100 \mu \mathrm{g}$ protein $\mathrm{ml}^{-1}$ ) or distilled water. The resultant suspensions were diluted to give suspensions containing $1.2 \mathrm{mg}$ and $0.6 \mathrm{mg}$ bacteria $\mathrm{ml}^{-1}$. Portions of $250 \mu \mathrm{l}$ of each were added to cubes of artificial diet and larvae were added and incubated at $27^{\circ} \mathrm{C}$ as before. All readings were performed in duplicate and mortalities were recorded every $24 \mathrm{~h}$ for $5 \mathrm{~d}$. Each experiment was repeated on a separate day.

\section{RESULTS}

\section{Chitinase activity and inhibition by allosamidin}

Supernatant extracts both of $B$. thuringiensis subsp. israelensis IPS78 and $B$. thuringiensis subsp. aizawai HD133 exhibited very similar chitinolytic activities

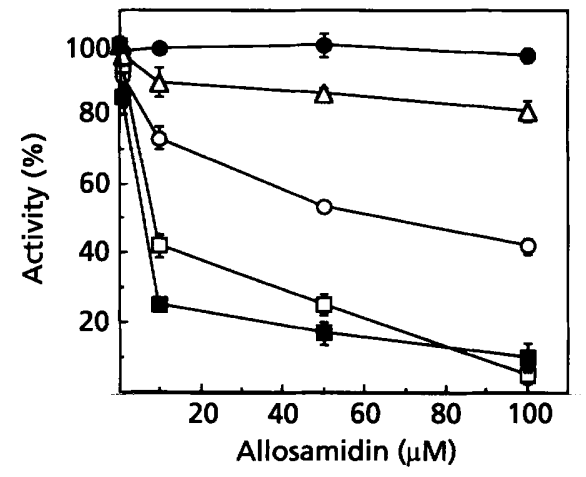

Fig. 1. Inhibition of chitinolytic activities of $B$. thuringiensis subsp. aizawai HD133 by allosamidin. Supernatant extracts were assayed against increasing concentrations of allosamidin $(0-100 \mu \mathrm{M})$. Activity was measured against a range of substrates: glycol chitin (O), 4-MeUmb-GleNAc (O), 4-MeUmb-

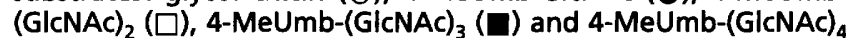
$(\triangle)$ for $30 \mathrm{~min}$ at $37^{\circ} \mathrm{C}$ in the citrate/phosphate buffer $\mathrm{pH} \mathrm{6.0.}$ Results are expressed as a percentage of the respective control value and are means of six replicates. Bars represent standard error values. Control values [fkat (mg protein $)^{-1}$ ] for the five substrates were, respectively: 13381 ( \pm 1103$), 2706$ ( \pm 172$)$, $46405( \pm 1200), 7500( \pm 442)$ and $1888( \pm 95)$. Results for $B$. thuringiensis subsp. israelensis were very similar.

Table 1. Effect of chitinase and allosamidin on the mortality levels of $C$. nubeculosus and $S$. littoralis treated with $B$. thuringiensis strains IPS78 and HD133

Suspensions were prepared as described in Methods. $\mathrm{LD}_{50}$ values are expressed as $\mu \mathrm{g}$ lyophilized culture used per bioassay (means $\pm 95 \%$ confidence limits).

\begin{tabular}{|lr|}
\hline Bioassay treatment & LD $_{50}$ \\
\hline C. nubeculosus larvae/strain IPS78 & \\
Water & $587 \pm 80$ \\
Allosamidin $(100 \mu \mathrm{M})$ & $743 \pm 98$ \\
Chitinase $\left(50 \mu \mathrm{g}\right.$ protein $\left.\mathrm{ml}^{-1}\right)$ & $439 \pm 59$ \\
Chitinase $\left(125 \mu \mathrm{g}\right.$ protein $\left.\mathrm{ml}^{-1}\right)$ & $143 \pm 25$ \\
Chitinase $\left(250 \mu \mathrm{g}\right.$ protein $\left.\mathrm{ml}^{-1}\right)$ & $103 \pm 32$ \\
S. littoralis larvae/strain $\mathrm{HD}^{133}$ & \\
Water & $716 \pm 96$ \\
Allosamidin $(100 \mu \mathrm{M})$ & $1006 \pm 99$ \\
Chitinase $\left(50 \mu \mathrm{g}\right.$ protein $\left.\mathrm{ml}^{-1}\right)$ & $271 \pm 60$ \\
Chitinase $\left(100 \mu \mathrm{g}\right.$ protein $\left.\mathrm{ml}^{-1}\right)$ & $139 \pm 25$ \\
\hline
\end{tabular}

against all substrates tested, suggesting that they produce a mixture of enzymes with different types of activities (Fig. 1 shows results for HD133). Allosamidin inhibited the chitinolytic activities of both extracts in a very similar fashion (Fig. 1 shows results for HD133). $\mathrm{IC}_{50}$ values for $B$. thuringiensis subsp. israelensis IPS78 and $B$. thuringiensis subsp. aizawai HD133 supernatant extracts using the Calcofluor assay were 43 and $63 \mu \mathrm{M}$ allosamidin, respectively, whereas $\mathrm{IC}_{50}$ values for 4$\mathrm{MeUmb}-(\mathrm{GlcNAc})_{2}$ and $4-\mathrm{MeUmb}-\left(\mathrm{GlcNAc}_{3}\right.$ were in the $1-10 \mu \mathrm{M}$ range. Negligible inhibition of activity was 


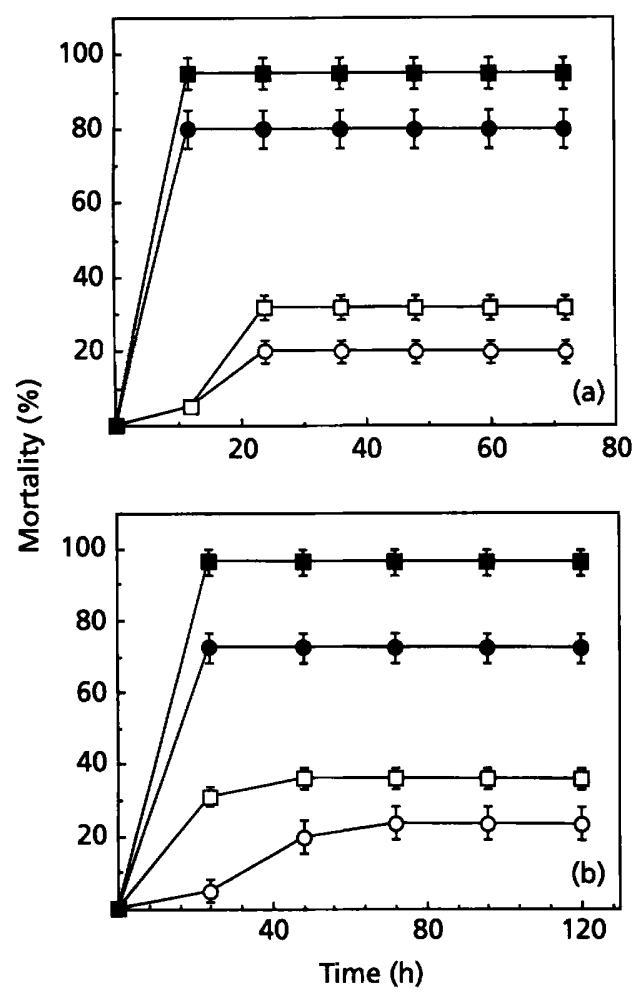

Fig. 2. Effect of chitinase $A$ on the killing rate of $B$. thuringiensis: (a) subsp. israelensis IPS78 against $C$. nubeculosus larvae and (b) subsp. aizawai HD133 against S. littoralis larvae. Mortality levels are of larvae treated with (a) IPS78 at concentrations of $1.5(\square)$ or $0.8 \mathrm{mg}(0)$ lyophilized culture $\mathrm{ml}^{-1}$ and chitinase $A\left(125 \mu \mathrm{g}\right.$ protein $\left.\mathrm{ml}^{-1}\right)$, or IPS78 at concentrations of $1.5(\square)$ or $0.8 \mathrm{mg}(O)$ lyophilized culture ml-1 and distilled water; and (b) HD133 at concentrations of $1.2(\square)$ or $0.6 \mathrm{mg}(0)$ lyophilized culture $\mathrm{ml}^{-1}$ and chitinase $A(100 \mu \mathrm{g}$ protein $\left.\mathrm{ml}^{-1}\right)$, or HD133 at concentrations of $1.2(\square)$ or $0.6 \mathrm{mg}$ (O) lyophilized culture $\mathrm{ml}^{-1}$ and distilled water. Bioassays were performed as described in Methods. Bars represent standard error values for four replicates.

observed using $4-\mathrm{MeUmb}-(\mathrm{GlcNAc})_{4}$ or $4-\mathrm{MeUmb}$ GlcNAc as substrates.

\section{Effect of allosamidin on toxicity}

Allosamidin $(100 \mu \mathrm{M})$ had a strong inhibitory effect on the toxicity of both $B$. thuringiensis subsp. israelensis IPS78 against larvae of C. nubeculosus and B. thuringiensis subsp. aizawai HD133 against larvae of $S$. littoralis (Table 1). The allosamidin solution by itself had no discernible effect on any larvae in these experiments.

\section{Effect of chitinase A on toxicity}

The presence of exogenous chitinase A greatly enhanced both the insecticidal activity and the rate of kill of $B$. thuringiensis subsp. israelensis IPS78 against larvae of C. nubeculosus and of B. thuringiensis subsp. aizawai HD133 against larvae of S. littoralis (Table 1, Figs 2 and 3). Controls using chitinase alone had no effect on any larvae used and the E. coli A992 supernatant fraction

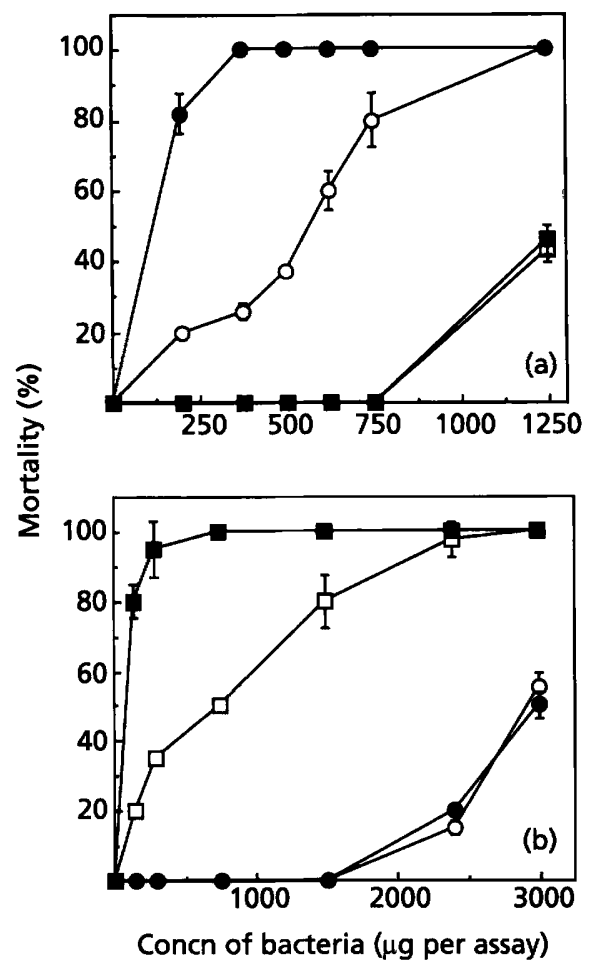

Fig. 3. Influence of chitinase $A$ on the insecticidal activities of B. thuringiensis subsp. israelensis IPS78 and subsp. aizawai HD133 against (a) C. nubeculosus larvae, after $3 \mathrm{~d}$, and (b) $S$. littoralis larvae, after $\mathbf{4} \mathrm{d}$. Mortality levels are of larvae treated with IPS78 plus chitinase A $\left(125 \mu \mathrm{g}\right.$ protein $\left.\mathrm{ml}^{-1}\right)(0)$ or distilled water $(O)$, and $\mathrm{HD} 133$ plus chitinase $A\left(100 \mu \mathrm{g}\right.$ protein $\left.\mathrm{ml}^{-1}\right)$ ( $\square$ ) or distilled water $(\square)$. All bioassays were performed as described in Methods. Bars represent standard error values for four replicates.

lacking the chitinase A plasmid produced no enhancement of insecticidal activity of either bacterial strain. In the cross-infection experiments, addition of exogenous chitinase had no effect on the weak entomocidal activity of $B$. thuringiensis subsp. israelensis IPS78 against larvae of $S$. littoralis or of $B$. thuringiensis subsp. aizawai HD133 against larvae of C. nubeculosus (Fig. 3).

\section{DISCUSSION}

Both strains of $B$. thuringiensis used in this study showed high chitinase activities, particularly for exochitinase. A range of other strains all showed lower activities, but a range of insecticidal strains of Bacillus sphaericus had no detectable activities (M. N. Sampson \& G.W. Gooday, unpublished).

Evidence for the importance of endogenous chitinase in the pathogenesis of $B$. thuringiensis is provided here by the observation of a decrease in insecticidal activity in the presence of the specific chitinase inhibitor allosamidin for both bacterial strains tested.

Inhibition of chitinase activities from the bacterial strains by allosamidin varied depending on the substrate used. Differences may be due to B. thuringiensis pro- 
ducing a mixture of chitinases with different affinities for allosamidin. Bacillus circulans WL-12, for example, produces at least nine chitinase molecules (Alam et al., 1996). Previous work has shown that allosamidin has a diverse spectrum of activities against chitinases, with very strong inhibition of activity of some fish and nematode chitinases, less strong inhibition of those of insects and fungi and the weakest effect on those of bacteria (Gooday, 1990). The inhibition of B. thuringiensis chitinase by allosamidin is comparatively weak, with $\mathrm{IC}_{50}$ values in the micromolar range; based on these results a high concentration of allosamidin $(100 \mu \mathrm{M})$ was used for the bioassay experiments.

In our experiments, allosamidin had no discernible effect on the larval stages of growth of either $C$. nubeculosus or S. littoralis. This is in contrast to reports of its insecticidal activity on developing insects. Thus it inhibited moulting and led to death of Bombyx mori and Leucania separata after being injected into larvae at different growth stages immediately after ecdysis (Sakuda et al., 1987a). When administered orally, allosamidin (synonym A82516) stopped Musca domestica larvae from forming pupae (Somers et al., 1987).

We have shown that addition of $S$. marcescens chitinase A enhances the activity of two strains of $B$. thuringiensis against hosts from different orders of insects. These results reinforce observations that the addition of commercial chitinase preparations enhances insecticidal activity of $B$. thuringiensis (e.g. Smirnoff, 1974). Studies on the mortality rate of baculovirus against its host also showed an increase in toxicity in the presence of added commercial chitinase preparation (Shapiro et al., 1987). Wiwat et al. (1996) transformed B. thuringiensis subsp. israelensis with chitinase-encoding genes from Aeromonas hydrophila and Pseudomonas maltophila with the aim of potentiating insecticidal activity, but only low levels of expression were obtained.

The observations that the addition of chitinase had no effect on death rates in the cross-infection experiments, i.e. strain IPS78 versus caterpillars, strain HD133 versus midge larvae (Fig. 3), required experiments with very high concentrations of bacteria, which would have led to high endogenous chitinase activities. These observations thus underline the host specificities of the two bacterial strains.

Our results are consistent with previous studies which have demonstrated a link between chitinase activity and pathogenicity of a range of microbial insect pathogens (Huber et al., 1991; Schlein et al., 1991; Fuhrman et al., 1995; Hawtin et al., 1997), and with those of Shahabuddin et al. (1993), who observed a blocking of transmission of the malarial parasite $P$. gallinaceum in the presence of allosamidin. The precise mechanism through which chitinase exerts its effect on insect pathogenesis in these different systems is unclear. One suggestion is that microbial chitinases partially digest the peritrophic membrane, aiding the microbes and/or their toxins to penetrate the peritrophic membrane (Shahabuddin \& Kaslow, 1993). Evidence for this hypothesis includes the observation that exogenous chitinase is capable of digesting the peritrophic membrane of the mosquito Aedes aegypti (Huber et al., 1991). By contrast, studies on the transmission of Trypanosoma brucei rhodesiense suggested that chitinolytic activity may not be required for the parasite to traverse the peritrophic membrane in tsetse flies, and a model was proposed whereby products of the action of chitinolytic endosymbiotic bacteria may inhibit the antiparasitic action of host defence lectins (Welburn et al., 1993).

The data presented here show a clear link between chitinase production and enhancement of virulence in $B$. thuringiensis, but further research is required to elucidate the functional role of chitinase activity.

\section{ACKNOWLEDGEMENTS}

We thank Drs D. J. Ellar and I. Chet for bacterial strains, Dr S. Sakuda for a sample of allosamidin, and Dr A. J. Mordue, Mrs M. Brown and Miss B. King for advice and assistance with the insect bioassays.

\section{REFERENCES}

Alam, M., Mizutani, T., Isono, M., Nikaidou, N. \& Watanabe, T. (1996). Three chitinase genes (chiA, chiB and $c h i C)$ comprise the chitinase system of Bacillus circulans WL-12. J Ferment Bioeng $82,28-36$.

Bot, J. (1967). Artificial rearing method for three noctuids of economical importance belonging to the genus Spodoptera. $J$ Entomol Soc Sth Afr 29, 157-160.

Carter, D. J. (1984). Spodoptera littoralis. In Pest Lepidoptera of Europe, pp. 274-275. Edited by D. J. Carter. Boston: Dr W. Junk Publishers.

deBarjac, H. (1981). Identification of H-serotypes of Bacillus thuringiensis. In Microbial Control of Pests and Plant Diseases, 1970-1980, pp. 35-43. Edited by H. W. Burges. London: Academic Press.

deBarjac, H. (1990). Characterisation and prospective view of Bacillus thuringiensis israelensis. In Bacterial Control of Mosquito and Blackflies, pp. 10-15. Edited by H. deBarjac \& D. J. Sutherland. Rutgers: Rutgers University Press.

Finney, D. J. (1962). Probit Analysis, 3rd edn. Cambridge: Cambridge University Press.

Fuhrman, J. A., Lee, J. \& Dalamagas, D. (1995). Structure and function of a family of chitinase isozymes from Brugian microfilariae. Exp Parasitol 80, 672-680.

Gooday, G. W. (1990). Inhibition of chitin metabolism. In The Biochemistry of Cell Walls and Membranes in Fungi, pp. 61-79. Edited by P. J. Kuhn, A. P. J. Trinci, M. J. Jung, M. W. Goosey \& L. G. Copping. Berlin: Springer.

Gooday, G. W. (1994). Physiology of microbial degradation of chitin and chitosan. In Biochemistry of Microbial Degradation, pp. 279-312. Edited by C. Ratledge. Dordrecht: Kluwer.

Gooday, G. W., Brydon, L. J. \& Chappell, L. H. (1988). Chitinase in female Onchocerca gibsoni and its inhibition by allosamidin. Mol Biochem Parasitol 29, 223-225.

Hawtin, R. E., Zarkowska, T., Arnold, K., Thomas, C. A., Gooday, G. W., King, L. A., Kuzio, J. A. \& Possee, R. D. (1997). Liquefaction of Autographa californica nucleopolyhedrovirus-infected insects 
is dependent on the integrity of virus-encoded chitinase and cathepsin genes. Virology 238, 243-253.

Huber, M., Cabib, E. \& Miller, L. (1991). Malaria parasite chitinase and penetration of the mosquito peritrophic membrane. Proc Natl Acad Sci USA 88, 2807-2810.

Kettle, D. S. (1977). Biology and bionomics of bloodsucking ceratopogonids. Annu Rev Entomol 22, 33-51.

Kuranda, M. J. \& Robbins, P. W. (1987). Cloning and heterologous expression of glycosidase genes from Saccharomyces cerevisiae. Proc Natl Acad Sci USA 84, 2585-2589.

McCreath, K. J. \& Gooday, G. W. (1992). A rapid and sensitive micro-assay for determination of chitinolytic activity. J Microbiol Methods 14, 229-237.

Milewski, S., O'Donnell, R. \& Gooday, G. W. (1992). Chemical modification studies of the active centre of Candida albicans chitinase and its inhibition by allosamidin. J Gen Microbiol 138, 2545-2550.

Molano, J., Duran, A. \& Cabib, E. (1977). A rapid and sensitive assay for chitinase using tritiated chitin. Anal Biochem 83, 648-656.

Regev, A., Keller, M., Strizhov, N., Sneh, B., Prudovsky, E., Chet, I., Ginzberg, I., Koncz-Kalman, Z., Koncz, C., Schell, J. \& Zilberstein, A. (1996). Synergistic activity of a Bacillus thuring$i e n s i s$-endotoxin and a bacterial endochitinase against Spodoptera littoris larvae. Appl Environ Microbiol 62, 3581-3586.

Sakuda, S., Isogai, A., Matsumoto, S. \& Suzuki, A. (1987a). Search for microbial insect growth regulators. II. Allosamidin, a novel insect chitinase inhibitor. J Antibiot 40, 296-300.

Sakuda, S., Isogai, A., Makita, T., Matsumoto, S., Koseki, K., Kodama, H. \& Suzuki, A. (1987b). Structures of allosamidins, novel insect chitinase inhibitors, produced by actinomycetes. Agric Biol Chem 51, 3251-3259.

Sampson, M. N. \& Gooday, G. W. (1996). A novel chitinase assay using the fluorescent brightener Calcofluor White M2R. In Chitin Enzymology, vol. 2, pp. 227-234. Edited by R. A. A. Muzzarelli. Grottammare: Atec Edizioni.

Schlein, Y., Raymond, L. J. \& Shlomai, J. (1991). Chitinase secreted by Leishmania functions in sandfly vector. Proc R Soc Lond Ser B 245, 121-126.

Shahabuddin, M. \& Kaslow, D. C. (1993). Chitinase: a novel target for blocking parasite transmission? Parasitol Today 9, 252-255.

Shahabuddin, M., Toyoshima, T., Aikawa, M. \& Kaslow, D. C. (1993). Transmission-blocking activity of a chitinase inhibitor and activation of malarial parasite chitinase by mosquito protease. Proc Natl Acad Sci USA 90, 4266-4270.

Shapiro, M., Preisler, H. K. \& Robertson, J. L. (1987). Enhancement of baculovirus activity on gypsy moth (Lepidoptera: Lymantriidae) by chitinase. J Econ Entomol 80, 1113-1116.

Smirnoff, W. A. (1974). Three years of aerial field experiments with Bacillus thuringiensis plus chitinase formulation against the spruce budworm. J Invertebr Pathol 24, 344-348.

Sneh, B., Schuster, S. \& Gross, S. (1983). Improvement of the insecticidal activity of Bacillus thuringiensis var. entomocidus on larvae of Spodoptera littoralis (Lepidoptera, Noctuidae) by addition of chitinolytic bacteria, a phagostimulant and a UVprotectant. Z Angew Entomol 96, 77-83.

Somers, P. J. B., Yao, R. C., Doolin, L. R., McGowan, M. J., Fakuda, D. S. \& Mynderse, J. S. (1987). Method for the detection and quantification of chitinase inhibitors in fermentation broths; isolation and insect life cycle. Effect of A82516. J Antibiot 40, 1751-1756.

Trudel, J. \& Asselin, A. (1989). Detection of chitinase activity after polyacrylamide gel electrophoresis. Anal Biochem 178, 362-366.

Welburn, S. C., Arnold, K., Maudlin, I. \& Gooday, G. W. (1993). Rickettsia-like organisms and chitinase production in relation to transmission of trypanosomes by tsetse flies. Parasitology 107, 141-145.

Wiwat, C., Lertcanawanichakul, M., Siwayapram, P., Pantuwatana, S. \& Bhumiratana, A. (1996). Expression of chitinaseencoding genes from Aeromonas hydrophila and Pseudomonas maltophila in Bacillus thuringiensis subsp. israelensis. Gene 179, 119-126.

Received 5 February 1998; revised 28 April 1998; accepted 4 May 1998. 